\title{
Notes on Lasioptera rubi (Schrank) (Diptera: Cecidomyiidae) and its larval parasitoids (Hymenoptera) on raspberries in Russia
}

\section{Ekaterina Yegorenkova \& Zoya Yefremova*}

\begin{abstract}
Yegorenkova, E. \& Yefremova, Z. 2016: Notes on Lasioptera rubi (Schrank) (Diptera: Cecidomyiidae) and its larval parasitoids (Hymenoptera) on raspberries in Russia. - Entomol. Fennica 27: 15-22.

In this paper, larva and pupa of Lasioptera rubi (Schrank) infected by hymenopteran parasitoids are illustrated. For the first time it is found that Platygaster pelias Walker is a solitary parasite and winters at the embryonal stage inside host larva of L. rubi reared from galls on Rubus idaeus stems in Russia. Lasioptera rubi, Torymus eadyi Graham \& Gijswijt and Platygaster pelias Walker are recorded from Russia for the first time.

E. Yegorenkova, Ulyanovsk State Pedagogical University, Department of Geography and Ecology, 100-letyia Lenina sq., 4, Ulyanovsk 432700 Russia; E-mail: egorenkova80@mail.ru

Z. Yefremova, The George S. Wise Faculty of Life Sciences, Department of Zoology, Tel Aviv University, Tel Aviv 69978 Israel. * Corresponding author's e-mail:eulophids@mail.ru
\end{abstract}

Received 11 June 2015, accepted 3 September 2015

\section{Introduction}

The raspberry stem gall midge Lasioptera rubi (Schrank, 1803) (Diptera, Cecidomyiidae) occurs from Western Europe to the Far East of Russia and Japan (Yukawa et al. 2014). In Russia, it is widely distributed in the middle and southern parts. It has also been recorded in western Siberia (the Yenisei Siberia) (Kolomoets et al. 1989, Gerasimchuk 2008) and near Krasnoyarsk (Gagne 2004).

The damage inflicted on raspberry (Rubus idaeus Linnaeus) by galls of $L$. rubi (Fig. 1a) inhibits the growth of plants and causes partial desiccation of stems, which may break due to strong winds. Galls may also reduce crop yields in raspberry. The raspberry stem gall midge (Fig. 2b) can fly for considerable distances (own unpublished data). The orange-red larvae (Fig. 3c) re- side under the bark of young stems, creating fusiform or irregularly globular swellings. Larvae cocoon, pupate and overwinter in the galls on the stems of raspberries and blackberries. In central Russia, the lengths of gall midge larvae observed by Batysheva (1982) are equal to 2.0-3.0 $\mathrm{mm}$ in $56.3-86.3 \%$ of cases and to $0.7-1.6 \mathrm{~mm}$ in others.

In Europe, the complex of parasitoids reared from $L$. rubi comprises 16 species of Chalcidoidea and one species of Platygastridae (Table 1). The assemblage includes four species of Aprostocetus and Sigmophora brevicornis (Eulophidae: Tetrastichinae), three species of Eupelmus, Eurytoma and Torymus each, one species of Pteromalidae and one of Platygaster (Platygastridae).

Here we illustrate the larval instars of L. rubi, report the development of its parasitoids, and pro- 
Table 1. Hymenopterous parasitoid species reared from Lasioptera rubi mines by different authors during 19662006.

\begin{tabular}{|c|c|c|}
\hline Parasitoid family and species & Authors & Country \\
\hline \multicolumn{3}{|l|}{ Eulophidae } \\
\hline Aprostocetus roesellae Nees, 1834 & $\begin{array}{l}\text { Domenichini 1966, } \\
\text { Herting } 1978\end{array}$ & $\begin{array}{l}\text { Italy, Great Britain, } \\
\text { Russia (Far East of Russia) }\end{array}$ \\
\hline A. rubi Graham, 1987 & $\begin{array}{l}\text { Graham } 1987, \\
\text { Jennings } 2005\end{array}$ & $\begin{array}{l}\text { Czechoslovakia (the } \\
\text { Czech Republic), Finland, } \\
\text { France, Germany, Sweden, } \\
\text { Yugoslavia (Serbia) }\end{array}$ \\
\hline A. rubicola Graham, 1987 & Graham 1987 & Germany \\
\hline A. tymber Walker, 1839 & $\begin{array}{l}\text { Domenichini 1966, } \\
\text { Simova-Tosic \& } \\
\text { Dobrivojevic 1966, } \\
\text { Bouek 1977, } \\
\text { Viggiani \&Mazzone } 1978\end{array}$ & $\begin{array}{l}\text { Austria, Czechoslovakia } \\
\text { (the Czech Republic), } \\
\text { France, Germany, Great } \\
\text { Britain, Hungary, } \\
\text { Netherlands, Sweden }\end{array}$ \\
\hline Sigmophora brevicornis (Panzer, 1804) & Thompson 1955 & Germany, France \\
\hline \multicolumn{3}{|l|}{ Eupelmidae } \\
\hline Eupelmus fulvipes Förster, 1860 & Bouček 1977, Herting 1978 & Yugoslavia (Serbia) \\
\hline E. urozonus Dalman, 1820 & $\begin{array}{l}\text { Simova-Tosic \& } \\
\text { Dobrivojevic1966, } \\
\text { Tudor \& Neacsu } 1983\end{array}$ & Yugoslavia (Serbia) \\
\hline E. vesicularis (Retzius, 1783) & $\begin{array}{l}\text { Thompson 1955, } \\
\text { Herting 1978, Viggiani } \\
\text { \& Mazzone 1978, } \\
\text { Tudor \& Neacsu } 1983\end{array}$ & $\begin{array}{l}\text { Germany, France, Italy, } \\
\text { Romania }\end{array}$ \\
\hline \multicolumn{3}{|l|}{ Eurytomidae } \\
\hline Eurytoma aterrima (Schrank, 1781) & Thompson, 1955 & Germany, France \\
\hline E. curculionum Mayr, 1878 & Bouček 1977 & Yugoslavia (Serbia) \\
\hline E. rosae Nees, 1834 & $\begin{array}{l}\text { Bouček } 1977, \\
\text { Popescu } 2006\end{array}$ & $\begin{array}{l}\text { Yugoslavia (Serbia), } \\
\text { Romania }\end{array}$ \\
\hline Sycophila submutica (Thomson, 1876) & Herting 1978 & Great Britain \\
\hline \multicolumn{3}{|l|}{ Pteromalidae } \\
\hline Mesopolobus rhabdophagae (Graham, 1957) & Herting 1978 & Great Britain \\
\hline \multicolumn{3}{|l|}{ Torymidae } \\
\hline Torymus chloromerus (Walker, 1833) & $\begin{array}{l}\text { Herting } 1978 \text {, } \\
\text { Stenseth } 1978\end{array}$ & Norway \\
\hline Torymus eadyi Graham \& Gijswijt, 1998 & $\begin{array}{l}\text { Graham \& Gijswijt 1998, } \\
\text { Popescu 2003, } \\
\text { Zerova \& Seryogina } 2003\end{array}$ & Great Britain, Ukraine \\
\hline T. rubi (Schrank, 1781) & $\begin{array}{l}\text { Bouček } 1977, \\
\text { Herting } 1978\end{array}$ & Yugoslavia (Serbia) \\
\hline \multicolumn{3}{|l|}{ Platygastridae } \\
\hline Platygaster pelias Walker, 1836 & Vlug 1995 & $\begin{array}{l}\text { England, Sweden, Spain, } \\
\text { Norway, Finland, Estonia, } \\
\text { Denmark }\end{array}$ \\
\hline
\end{tabular}

vide new ecological and faunistic data on parasitoids associated with this gall midge. Although Platygaster pelias Walker is well-known as a parasitoid of $L$. rubi, its life history has not been described in details.

\section{Materials and methods}

The study was carried out in June 2009-July 2010 in two localities of the Ulyanovsk Region: the village of Staraya Mayna $(68 \mathrm{~km} \mathrm{E}$ from 

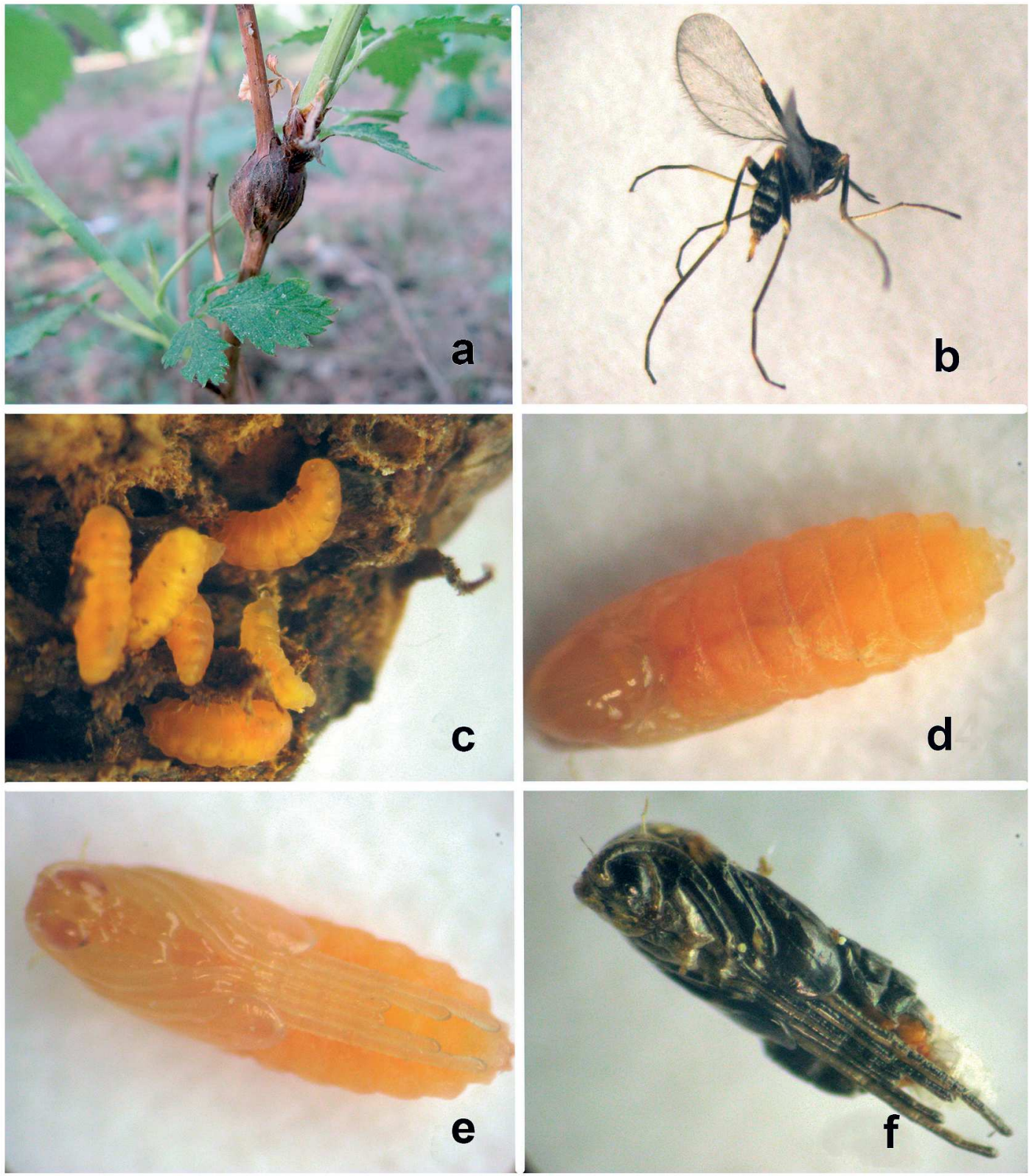

Fig. 1. Gall, male and immatures of Lasioptera rubi. - a. Gall on Rubus idaeus (6.6.2009, Ulyanovsk, Russia). b. Male (reared from a gall). $-c$. Third instar larvae (opened gall). $-d$. Young pupa, dorsal view. - f. Young pupa, ventral view. - f. Mature pupa (ventral view).

Ulyanovsk, $54^{\circ} 36^{\prime} \mathrm{N}, 48^{\circ} 55^{\prime} \mathrm{E}$ ) and the city of Ulyanovsk (the western bank of the river Volga, $54^{\circ} 19^{\prime} \mathrm{N}, 48^{\circ} 22^{\prime} \mathrm{E}$ ). Altogether 530 galls of $L$. rubi were collected on raspberries from these localities.

Part of the stem, together with a gall, comprising 5-7 $\mathrm{cm}$ on either side of the gall, was cut from the lower and middle parts of the stem. After cut- ting the stems, galls of $L$. rubi were placed in plastic vials $(80 \times 15 \mathrm{~mm})$ with filter paper and were kept in the laboratory at a temperature of $+20-22$ ${ }^{\circ} \mathrm{C}$ and shaded from direct sunlight. Selected emergent adults were killed in $75 \%$ ethanol for identification.

A total of 153 galls were dissected to determine the number of larvae of $L$. rubi per gall. The 
remaining 377 galls were kept in containers for further rearing: $20 \%$ of them became moldy ( 76 galls), and the rest yielded a total of $582 \mathrm{~L}$. rubi adults, 178 specimens of Platygaster pelias (Proctotrupoidea: Platygastridae), 28 specimens of Aprostocetus rubi (Chalcidoidea: Eulophidae) and 17 specimens of Torymus eadyi (Chalcidoidea: Torymidae). The parasitoids were identified using the keys provided by Trjapitzin (1978), Storozheva et al. (1995) and Buhl (2006). Voucher specimens are deposited in the Zoological Institution of Russian Academy of Sciences (ZISP), St.-Petersburg, Russia.

\section{Larval and pupal stages of Lasioptera rubi}

Dissected galls revealed different numbers of the raspberry stem gall midge larvae (3-5 larvae in 32 cases, 6-8 in 61 cases, $9-11$ in 45 cases and $13-14$ in 15 cases). Most galls $(69 \%)$ contained from 6 to 11 larvae $($ average $=7.91, S . D .=3.15, n$ $=153$ ).

The third instar larva of $L$. rubi is initially orange-yellow (Fig.1c). At 3.0-3.5 mm length it begins to pupate and young pupa is still orangeyellow dorsally and ventrally (Fig. 1d, e). The pupa is subsequently turning dark-brown and matures (Fig. 1f).

\section{Hymenopteran parasitoids infecting larvae of $L$. rubi}

No hymenopterous pupal parasitoids were found in this study.

\subsection{Platygaster pelias Walker, 1836 (Platygastridae)}

Material. The species was represented by 178 specimens: $110 q, 10 \hat{\delta}$, reared from galls of L. rubi on stems of $R$. idaeus 15.7.2009, Ulyanovsk, 6.6.2009 E. N. Yegorenkova leg.; 50, $8 \AA$, reared from galls of $L$. rubi on stems of $R$. idaeus 20.7.2010, Staraya Mayna, Ulyanovsk province, 14.VI.2010 E. N. Yegorenkova leg.

Comments. This species is distributed in Eng- land, Sweden, Spain, Norway, Finland, Estonia and Denmark (Vlug 1995, Austin et al. 2005, Buhl 2006), and in this study as a new record in Russia.

Biology. The species is a larval parasitoid of Orthoptera, Hemiptera, Neuroptera, Coleoptera, Diptera and Lepidoptera. Among Cecidomyiidae (Diptera), L. rubi has also been mentioned (Vlug 1995).

Platygaster pelias, an egg-larval parasitoid, has never been mentioned from Russia (Buhl 2006). We observed the eggs and larvae of $L$. rubi infected by $P$. pelias (Fig. 2a). It means that the parasitoids overwinter as embryos. In spring of the following year, the parasitoids develop and emerge in July. Sex ratio (males:females) for adults of $P$. pelias reared in laboratory was 18:160. A dark yellow-brownish pre-pupa of $P$. pelias is clearly visible inside the $L$. rubi larva, to which it is attached by a filament (Fig. 2b). The sternal spatula of $L$. rubi is also visible in ventral view. The adult of $P$. pelias breaks through the head of the $L$. rubi larva using its mandibles to make a hole (Fig. 2c). In all cases there was one $P$. pelias pupa per prepupal larva of the host that formed a single parasitoid (Fig. 2b, c). This suggests that only one parasitoid larva develops in each host, and therefore it is a solitary parasitoid. Several larvae of $L$. rubi were found with $P$. pelias that had reached the adult stage. So this species of Platygaster is monembryonic as for example Platygaster matsutama Yoshida \& Hirashima that has been reared from Thecodiplosis japonensis (Diptera: Cecidomyiidae) (Jeon et al. 1985). We establish solitary parasitism of $P$. pelias in $L$. rubi for the first time.

\subsection{Torymus eadyi Graham \& Gijswijt, 1998 (Torymidae)}

Material. The species (Fig. 2f) was represented by 21 specimens: $14+, 3 \bigcirc$, reared from galls of $L$. rubi on R. idaeus stems, 15.VII.2009, Ulyanovsk,

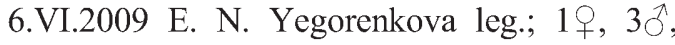
reared from galls of $L$. rubi on $R$. idaeus stems, 20.VII.2010, Staraya Mayna, Ulyanovsk province, 14.VI.2010 E. N. Yegorenkova leg.

Comments. The species is distributed in Bulgaria, France, Netherlands, Romania, Ukraine 


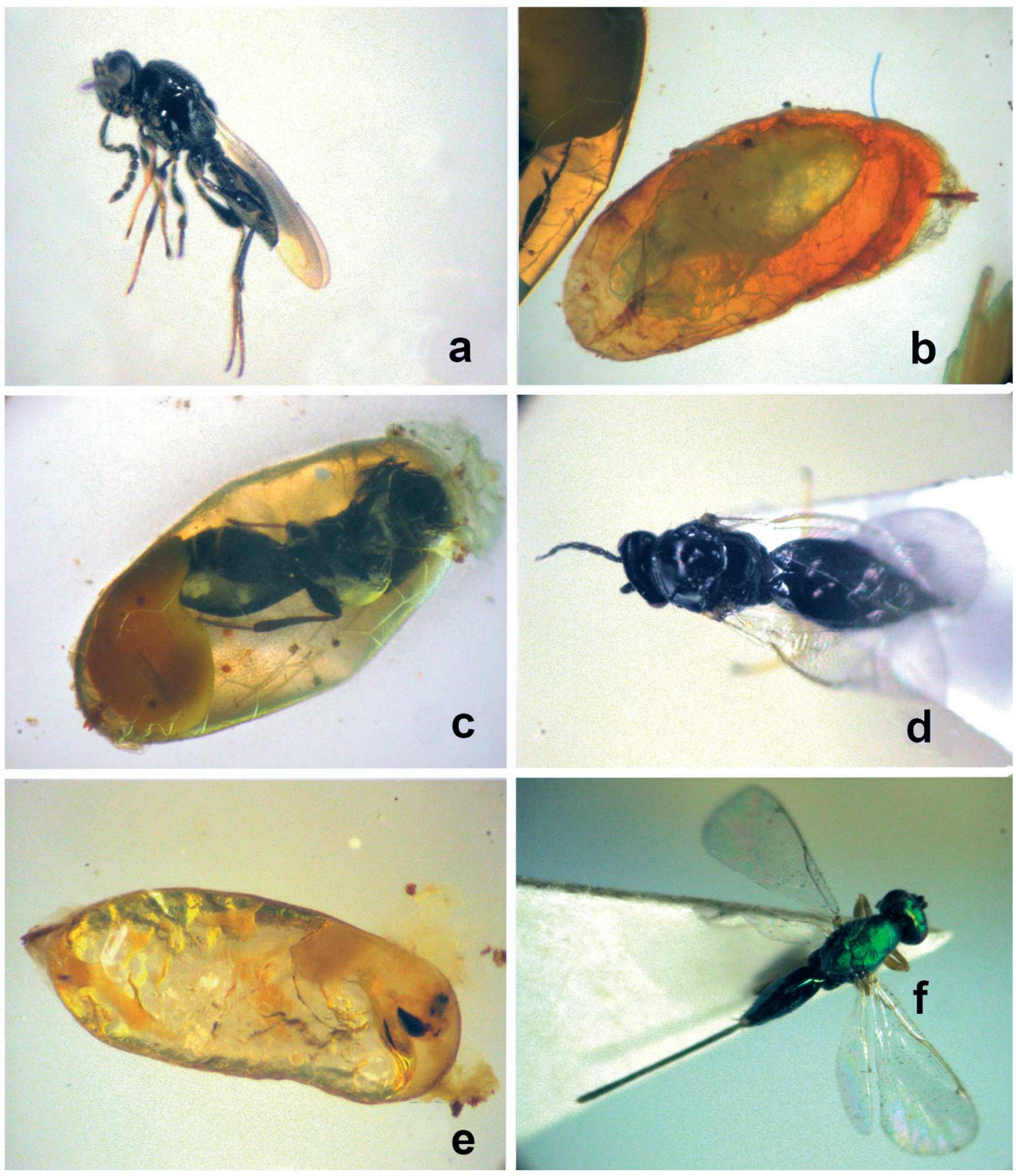

Fig. 2. Parasitoids of Lasioptera rubi. - a. Male Platygaster pelias. - b. Pre-pupa P. pelias inside larva of $L$. rubi (ventral view). $-\mathrm{c}$. Hatching adult of $P$. pelias (ventral view) from larva of $L$. rubi (dorsal view). - d. Female Aprostocetus rubi. - e. Pre-pupa of $A$. rubi (lateral-ventral view) inside larva of $L$. rubi (head of parasitoid larva visible). $-\mathrm{f}$. Female Torymus eadyi.

and England (Graham \& Gijswijt 1998, Zerova \& Seryogina 2003), and in this study as a new record in Russia as it has not been recorded from the Middle Volga Region and Russia earlier (Zerova \& Seryogina 2003).
Lasioptera rubi has always been mentioned as the only host of $T$. eadyi (Graham \& Gijswijt 1998, Popescu 2003, Zerova \& Seryogina 2003). Female:male ratio for reared adults was 15:6. 


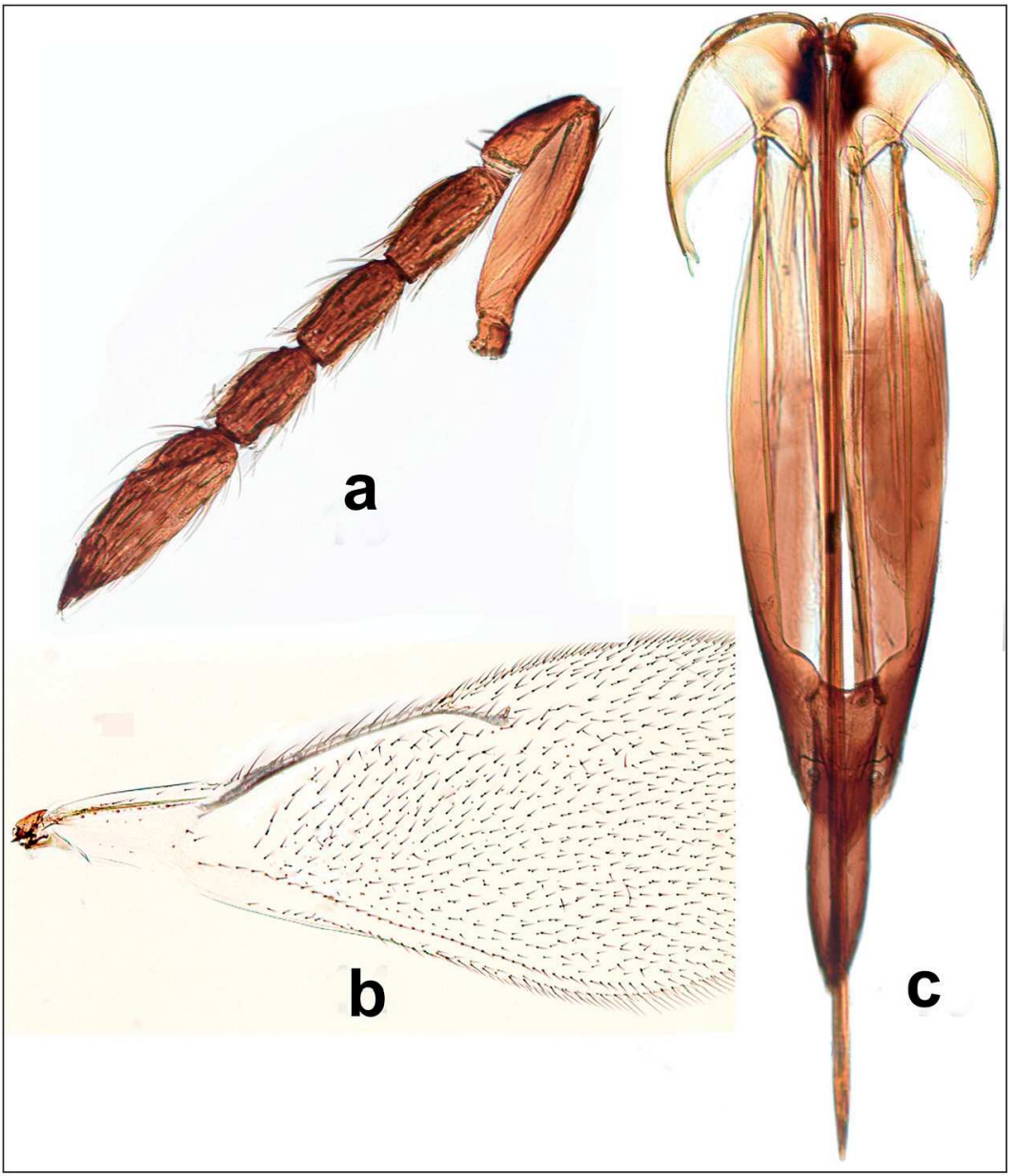

Fig. 3. Details of Aprostocetus rubi female. - a. Antenna. - b. Forewing. - c. Ovipositor.

\subsection{Aprostocetus rubi Graham, 1987 (Eulophidae)}

Material. Only females were reared: 28 , reared from galls of $L$. rubi on $R$. idaeus stems, 10.12.VIII.2009, Ulyanovsk, 6.VI.2009 E. N. Yegorenkova leg.

Other material examined. 19, Germany Baden, Wurttembert, Heilbronn, 3.V.2006 ex Lasioptera rubi, K. Schrameyer leg., S. Schmidt det. 2007.

Additions to original description (Graham 1987). Female (Fig. 2d) (length 1.3-1.9 mm) (1.8-2.5 mm in Graham 1987). Body black. Antennae fuscous. Legs yellowish with black coxae. POL (The minimum distance between the posterior ocelli) 2.0 times as OOL (The minimum distance between the eye margin and the nearest posterior ocellus). Antenna with 3 anelii (Fig. 3a).
Propodeum 3.1-3.2 times as broad as long, strongly reticulate with median carina, callus with 1 seta. Distance between submedian lines 1.4 times that between submedian and lateral lines. Dorsellum 1.25 times as long as propodeum Forewing (Fig. 3b): Marginal vein of forewing with 10-11 setae (10-15 in Graham 1987). Last tergite as long as broad (1.0-1.4 in Graham 1987). Ovipositor sheaths projecting by $0.26 \times$ length of last tergite (0.2-0.5 in Graham 1987).

Genitalia (Fig. 3c): outer plates of ovipositor (T9+T10) 3.1 times as long as broad, 1.3 times as long as inner plates of ovipositor, and 3.3 times as long as ovipositor sheaths. First and second valvulae 1.1 times as long as projecting part of sheaths.

Comments. The species is distributed in the Czech Republic, Finland, France, Germany, Netherlands, Sweden, United Kingdom, Yugo- 
slavia (Serbia) (Graham 1987)) and Far East of Russia (Storozheva et al. 1995, Yefremova 2002) and has been mentioned as a host of $L$. rubi (Graham 1987, Jennings 2005) and Diastrophus rubi (Bouché 1834) (Hymenoptera: Cynipidae) (Askew et al. 2006). Aprostocetus rubi has not been reared from galls in the Middle Volga Region earlier, it had been collected only by sweeping (Yegorenkova et al. 2007). In some cases the prepupa of $A$. rubi may occupy almost $90 \%$ of the volume of the host body (Fig. 2e). It means that it is a solitary endoparasitoid. In Fig. 2e, a well-developed head of a parasitoid is adjacent to the head of the host larva, whose dark-coloured eyes are clearly visible.

Acknowledgements. We are grateful to Netta Dorchin (Department of Zoology, Tel Aviv University, Tel Aviv, Israel) for clarification about the developmental stages of $L$. $r u b i$, and to Peter Neerup Buhl (formerly Zoological Museum, University of Copenhagen, Denmark) for confirmation of P. pelias identification. We thank Naomi Paz (Tel Aviv University) for her help in improving the language of the manuscript. We are also obligated to two anonymous reviewers for their efforts which greatly improved this paper.

\section{References}

Askew, R. R., Plantard, O., Gómez, J. F., Hernandez, N. M. \& Nieves-Aldrey, J. L. 2006: Catalogue of parasitoids and inquilines in galls of Aylacini, Diplolepini and Pediaspidini (Hym., Cynipidae) in West Palaearctic. - Zootaxa 1301: 3-60.

Austin, A. D., Johnson N. F. \& Dowton, M. 2005: Systematics, evolution, and biology of scelionid and platygastrid wasps. - Annual Review of Entomology 50: $553-582$.

Batysheva, Z. N. 1982: Biologia i ekologia osnovnyh vrediteley maliny na yuge nechernozemnoy zony RSFSR [Biology and ecology of major pests of raspberries in the south central region of the non-chernozem zone of the Russian Federation]. Abstract of the thesis for the degree of Candidate of Biological Sciences. - Timiryazev Agricultural Academy, Moscow, 18 pp. [In Russian.]

Bouček, Z. 1977: A faunistic review of the Yugoslavian Chalcidoidea (Parasitic Hymenoptera). - Acta entomologica Jugoslavica 13 (Supplement): 1-145.

Buhl, P. 2006: Key to Platygaster (Hymenoptera, Platygastridae) from Denmark, with descriptions of new species. - Steenstrupia 29(2): 127-167.

Domenichini, G. 1966: Hym. Eulophidae. Palaearctic Tetrastichinae. - In: Delucchi, V. \& Remaudičre, G. (eds), Index of Entomophagous Insects, Vol. 1:1-101. Le François, Paris. 101 pp.

Gagne, R. J. 2004: A catalog of the Cecidomyiidae (Diptera) of the world. - Memoirs of the Entomological Society of Washington 25: 1-408.

Graham, M. W. R. de V. 1987: A reclassification of the European Tetrastichinae (Hymenoptera: Eulophidae), with a revision of certain genera. - Bulletin of the British Museum (Natural History). Entomology 55(1): 1-319.

Graham, M. W. R. de V. \& Gijswijt, M. J. 1998: Revision of the European species of Torymus Dalman (s. lat.) (Hymenoptera: Torymidae). - Zoologische Verhandelingen, Leiden 317: 88-90.

Gerasimchuk, A. V. 2008: Phytophagous gall midges (Diptera, Cecidomyiidae) on plants of southern Middle Siberia, and their identification by the damage. In: Baranov, A. A. (ed.), Fauna and ecology zhivotnyh Central Siberia and the Far East. Issue 5: 132-141 Krasnoyarsk State Pedagogical University, Krasnoyarsk. 298 pp. [In Russian.]

Herting, B. 1978: Neuroptera, Diptera, Siphonaptera. A catalogue of parasites and predators of terrestrial arthropods. Section A. Host or Prey/Enemy, 5. - Commonwealth Agricultural Bureaux, Commonwealth Institute of Biological Control, Ottawa, Ontario, Canada. 156 pp.

Jennings, M. T. 2005: Aprostocetus rubi Graham, 1987 (Hym., Eulophidae) new to Britain. - Entomologist's Monthly Magazine 141(1694/1696): 150.

Jeon, M. J., Lee, B. Y. \& Ko, J. H. 1985: Ecology of Platygaster matsutama and Inostemma seoulis (Hymenoptera: Platygastridae), egg-larval parasites of the pine needle gall midge, Thecodiplosis japonensis (Diptera, Cecidomyiidae). - Esakia 23: 131-143.

Kolomoets, T. P., Mamaev, B. M., Zerova, M. D., Narchuk, E. P., Ermolenko, V. M. \& Dyakonchuk, M. A. 1989: Nasekomye-galloobrazovateli kul'turnyh i dikorastushih rasteniy evropeyskoy chasti SSSR. Dvukrylye [Gall-forming insects of cultivated and wild plants of the European part of the USSR. Diptera]. Naukova Dumka, Kiev. 168 pp. [In Russian.]

Popescu, I. E. 2003: Torymid wasps (Hymenoptera, Chalcidoidea, Torymidae) new for Romanian fauna. Analele Științifice Univ. "Alexandru Ioan Cuza" din Iaşi (Biologie animală) 49: 83-86.

Popescu, I. E. 2006: Torymid and eurytomid wasps (Hymenoptera, Chalcidoidea: Torymidae, Eurytomidae) of Piatra Craiului National Park (Brasov, Romania): 170-177. - In: Pop, E. G. (ed.), Research in Piatra Craiului National Park, 2. Editura Universitatii "Transilvania", Brasov. 270 pp.

Simova-Tosic, D. \& Dobrivojevic, K. 1966: The raspberry stem gall midge (Lasioptera rubi Heeg.) a little known pest of raspberry. — Zastita Bilja, Beograd 91/92: 323-330.

Stenseth, C. 1978: The life-cycle of the raspberry gall midge, Lasioptera rubi Schrank. — Gartneryrket 68: 266 268.

Storozheva, N. A., Kostjukov, V. V. \& Efremova, Z. A. 
1995: Family Eulophidae: 291-505. — In: Ler P. A. (ed.), Keys to Insects of the Russian Far East, 4(2). Dal'nauka, Vladivostok. 600 pp. [In Russian.]

Viggiani, G. \& Mazzone, P. 1978: Infestations by Lasioptera rubi (Schrank) (Diptera, Cecidomyiidae) in raspberry beds in southern Italy. - Informatore Fitopatologico 28(2): 3-4.

Vlug, H. J. 1995: Catalogue of the Platygastridae (Platygastroidea) of the world (Insecta: Hymenoptera). - In: Achterberg, C. (ed.), Hymenopterorum Catalogus, Pars 19: 1-168. SPB Academic Publishing BV, Amsterdam.

Thompson, W. R. 1955: A catalogue of the parasites and predators of insect pests. Section 2. Host parasite catalogue, Part 3. Hosts of the Hymenoptera (Calliceratid to Evaniid): 191-332. — Commonwealth Agricultural Bureaux, The Commonwealth Institute of Biological Control, Ottawa, Ontario, Canada. 345 pp.

Trjapitzin, V. A. 1978: Hymenoptera II. Chalcidoidea 13. Eulophidae (excl. Tetrastichinae). — In: Opredeliteli nasekomykh Evropeyskoy chasti SSSR [Keys for the identification of insects of the European Part of the
USSR], 3: 381-430. Nauka, Leningrad. 756 pp. [In Russian.]

Tudor, C. \& Neacsu, P. 1983: Contribution to the knowledge of chalcidoidea parasites of gall-forming cecidomyiids. - Studii şi cercetări de biologie. (Biologie animală) 35(1): 18-22.

Yegorenkova, E. N., Yefremova, Z. A. \& Kostjukov, V. V. 2007: To the study of the subfamily Tetrastichinae (Hymenoptera: Eulophidae) in the Middle Volga. Entomologicheskoe obozrenie 86(4): 781-796. [In Russian.]

Yefremova, Z. A. 2002: Catalogue of the Eulophidae (Hymenoptera: Chalcidoidea) of Russia. - Linzer Biologische Beiträge 34(1): 563-618.

Yukawa, J., Tokudo, M. \& Yamagishi, K. 2014: Host plant ranges and distribution records and unidentified species of the genus Lasioptera (Diptera; Cecidomyiidae) in Japan. - Esakia 54: 1-15.

Zerova, M. D. \& Seryogina, L. Y. 2003: Torymid chalcid wasps (Hymenoptera, Chalcidoidea, Torymidae) of tribe Torymini of the Ukrainian Fauna. - Vestnik zoologii, Kiev (Supplement) 17: 3-83. 